\title{
Historia arquitectónica de la iglesia de San José de Pelarco
}

$(1787-2011)^{1}$

\author{
Leonor Riesco Tagle $\left(^{*}\right)$
}

\begin{abstract}
RESUMEN
A pesar de constituir uno de los templos más antiguos de la provincia de Talca, la historia de la iglesia de San José de Pelarco ha sido escasamente investigada. Esta parroquia, fundada en 1787 por el Obispo de Santiago Manuel de Alday y Axpée, ha tenido dos templos. El segundo, que ha perdurado desde su erección (1855) hasta nuestros días no obstante los sucesivos movimientos telúricos en la zona, es un valioso exponente de la arquitectura neogótica en Chile, lo cual implica un valor agregado a su antigua construcción. Este hecho, junto con el interés por rescatar del olvido los archivos parroquiales, ha propulsado el anhelo de dar a conocer de la manera más completa posible la historia y evolución de la iglesia de San José de Pelarco, desde su primer edificio hasta el que podemos apreciar hoy en día.
\end{abstract}

\section{Palabras clave:}

Pelarco - historia parroquial - arquitectura religiosa.

\footnotetext{
(*) Licenciada en Historia, Universidad Finis Terrae. Diplomada y Magíster en Humanidades y Arte, Universidad Gabriela Mistral, Chile.

Artículo recibido el 2 de mayo de 2012. Aceptado por el Comité Editorial el 5 de septiembre de 2012.

Correo electrónico: leonor.riesco@yahoo.es

${ }^{1}$ Quisiera agradecer de manera especial a Claudia Fuentes, de la Comisión de Reconstrucción de la diócesis de Talca, y al padre Andrés Pérez, párroco de San José de Pelarco, por permitirme el acceso a las fuentes del Obispado de Talca y de la parroquia de Pelarco; y a Horacio Aránguiz Donoso, Hernán Rodríguez Villegas y Álvaro Góngora Escobedo, por la revisión y oportunas correcciones a este trabajo. También a Joannon Arquitectos, por facilitarme los planos de la iglesia y casa parroquial adjuntos.
} 


\begin{abstract}
San José de Pelarco is one of the oldest parish churches in the province of Talca and yet the architectural history of its temple has attracted little research. This parish was founded in 1878 by Manuel de Alday y Axpée, Bishop of Santiago, and had two different temples. The second has endured to our days since its foundation in 1855, having faced major earthquakes and it is a sample of neo-gothic architecture in Chile. This interesting architectural feature along with the need to rescue the parochial archives from oblivion has motivated the desire to study the history and evolution of this parish temple.
\end{abstract}

Keywords:

Pelarco - parish history - religious architecture.

\title{
I. Introducción
}

Reconstruir la historia de la arquitectura, ornamentación y enseres de la iglesia de San José de Pelarco desde su fundación hasta nuestros días no es tarea exenta de dificultades, pues a la escasa historiografía se añade con frecuencia su carácter impreciso y ambiguo. En la actualidad, el único trabajo que trata exclusivamente la evolución arquitectónica de este edificio es el del pelarquino Lautaro Vivar Encina, titulado Historia de la aldea "San José de Pelarco" (1994). Pero esta obra inédita contiene reiterados errores cronológicos y de información, pues se basa principalmente en el testimonio de sus habitantes y no hace mayor referencia a los archivos parroquiales y arzobispales, lo que le quita credibilidad y la hace bastante cuestionable. Por su parte, el riguroso trabajo de Horacio Aránguiz Donoso, Notas para el estudio de una parroquia rural del siglo XVIII: Pelarco 1786-1796 (Santiago, 1969), aporta valiosa información relativa a los orígenes de la parroquia y su feligresía, mas no sobre la obra edilicia ni sus posesiones.

Aparte de las dos obras mencionadas, hay otras que si bien no han contribuido con información especialmente novedosa, han ayudado a completar y contextualizar este estudio. Tal es el caso de Historia de Talca: 1742-1942 (Santiago, 1942), del historiador Gustavo Opazo Maturana; Haciendo memoria en los ochenta años de la Diócesis de Talca (Talca, 2005), de Monseñor Carlos González Cruchaga; y Las primeras capillas e iglesias (con la categoría de Monumento Histórico y/o Zona Típica) en la Región del Maule: una mirada sistémica (Talca, 2010), de Álvaro Labra².

\footnotetext{
${ }^{2}$ También han sido consultadas las obras de Julio Cárdenas, Memoria del Maule (Talca, 2005); María Angélica Fernández, Religiosidad popular en la Diócesis de Talca: vivencias que evangelizan (Santiago, 2006); Jorge Ibáñez Vergara, Don Nicolás de la Cruz Bahamonde: el Conde de Maule (Talca, 1997); Isabel González Martin, Talca, la muy noble y muy leal. 250 años de historia (1742-1992) (Talca, 1992); Jorge Valderrama Gutiérrez, Episodios históricos talquinos (Talca, 2008); José Luis Uribe Ortiz, Disecciones. La arquitectura de las infraestructuras públicas en Talca (Talca, 2001); Simón Sanhueza Torrealba, Estudio de los daños del terremoto de Talca de 1928 (Santiago, 2002); Recaredo Santos Tornero, Chile ilustrado. Guía descriptivo del territorio de Chile, de las capitales de provincia, de los puertos principales (Valparaíso, 1872); Juan Ignacio Molina, Compendio de la historia geográfica, natural y civil del Reino de Chile (Santiago, 2000); Gustavo Ramírez Vergara, Reducción de los fondos para la construcción de obras proyectadas en la provincia de Talca. Observaciones (Santiago, 1965); Dirección Regional de Turismo Séptima Región, Guía de museos y monumentos de la Región del Maule (Talca, 2002) y Bienvenidos al Maule: el corazón de Chile 2004 (Talca, 2004); Gobierno Regional del Maule, ¿Tiene Historia mi ciudad? Talca 2010 (Talca, 2010); Universidad de Talca, Talca y su muy noble historia (Talca, 1994); y Programa Puente (Chile), Testimonios de un Chile solidario en la Región del Maule (Talca, 2005).
} 
Pero el verdadero aporte de información descansa en las fuentes primarias, es decir, los archivos eclesiásticos del Arzobispado de Santiago y del Obispado de Talca, y los libros de fábrica de la parroquia, todos ellos fundamentales para reconstruir la historia arquitectónica de la iglesia de Pelarco y su casa parroquial. Los libros de fábrica ofrecen valiosos detalles sobre los gastos cotidianos y extraordinarios; las reparaciones en ambas construcciones; las nuevas adquisiciones tales como candelabros, manteles, instrumentos musicales, imágenes y otro tipo de elementos funcionales y ornamentales; la compra, venta y donaciones de terrenos; etcétera. Por su parte, los archivos del Obispado de Talca y del Arzobispado de Santiago conservan apreciables referencias relativas a los daños tras los sismos y sus respectivos presupuestos de reparación; los títulos de terrenos parroquiales y los trámites para la traslación de la iglesia y casa parroquial en 1885 -hecho hasta ahora desconocido por la historiografía- así como para su nombramiento como Monumento Histórico Nacional en 2002.

\section{Los inicios: Fundación de la parroquia}

A fines del siglo XVIII, la localidad de Pelarco ("agua de escarcha" en mapudungun) no era más que "un caserío de escasísima importancia en una zona árida y sólo servía de tambo en el camino que iba a los lugares más apartados de la cordillera, especialmente a la estancia de El Picaso, perteneciente a los Agustinos; a El Carretón; El Astillero; Huencuecho y la actual comunidad de Ligueno"3. Sin embargo, al encontrarse en la intersección del antiguo Camino Real -que unía a las villas de San Agustín de Talca y San José de Buenavista de Curicó- con aquel que unía la cordillera y el litoral, fue incrementando poco a poco el número de sus habitantes, reunidos "en torno a una pequeña capilla y algunas fondas y posadas donde se detenían a descansar los viajeros" ${ }^{\prime 4}$.

San José de Pelarco constituía una doctrina sujeta al curato de Talca, que a su vez dependía del Obispado de Santiago. Las doctrinas eran territorios rurales difusamente delimitados, atendidos por sacerdotes misioneros o doctrineros, los cuales evangelizaban e impartían los sacramentos a sus habitantes -que en un principio eran exclusivamente indios encomendados. La mayoría de las veces, estas doctrinas o "parroquias de indios" no contaban con un templo propio para el culto, sino que se hacía uso de las capillas privadas de los encomenderos. Pero con el tiempo, muchas doctrinas aumentaron considerablemente el número de sus feligreses, haciéndose indispensable la erección de parroquias o curatos que les otorgaran mayor autonomía y un registro más exhaustivo de los sacramentos impartidos. En varias ocasiones, estas parroquias sirvieron de punto de partida para la fundación de villas o ciudades, amén de constituir un punto de referencia importante en los centros poblados 5 .

En el caso particular de Pelarco, a fines de la década de 1780 ya contaba con casi tres mil feligreses, cifra nada despreciable para una doctrina ${ }^{6}$. Pero cuando en 1786 el

\footnotetext{
${ }^{3}$ Aránguiz Donoso, Horacio, Notas para el estudio de una parroquia rural del siglo XVIII: Pelarco 1786-1796, Universidad Católica de Chile, Santiago, 1969, p. 37.

4 "Conoce tu región: la iglesia San José de Pelarco, Monumento Nacional", en: diario digital El Amaule, $1^{\circ}$ de enero de 2007, http://www.elamaule.cl/admin/render/noticia/7438 [Consulta: 3 de diciembre 2011].

${ }^{5}$ González Cruchaga, Carlos, Haciendo memoria en los ochenta años de la Diócesis de Talca, Universidad Católica del Maule, Talca, 2005, pp. 23-24

${ }^{6}$ Ibíd., p. 178.
} 
Vicario del curato de Talca (Pedro Pablo de la Carrera) renunció a su tuición, el cura doctrinero de Pelarco, a la sazón fray Justo Alvarado -antiguo cura de Longocura, actual Curepto-, tuvo que asumir una mayor responsabilidad al aumentar sus labores misioneras. Esto, junto con la inexistencia de archivos que permitieran un registro ordenado, llevó a fray Justo a exponerle la compleja situación al Obispado de Santiago, solicitando erigir la doctrina de San José de Pelarco en parroquia ${ }^{7}$.

La solicitud fue acogida por Manuel de Alday y Axpée, Obispo de la capital, y el 17 de diciembre de 1787 se dictó el siguiente auto de erección:

"En la ciudad de Santiago de Chile, en diez y siete días del mes de diciembre de mil setecientos ochenta y siete años. El Ilustrísimo señor Doctor don Manuel de Alday, Obispo de esta santa iglesia catedral, del Consejo de Su Majestad, mi señoría. Habiendo visto los autos formados sobre la división del territorio que hay entre el río Claro y el de Lircay, y su erección en nueva parroquia, separándolo del curato de la Villa de San Agustín de Talca, en virtud de la renuncia que ha hecho don Pedro Pablo de la Carrera, cura y vicario de ella, dijo que, atendiendo a las justas causas que hay para ella y al consentimiento por el patronato real que recae en la Real Audiencia gobernadora, declaraba y declaró haber lugar a la división; y en su conformidad erigía y erigió en nueva parroquia el expresado territorio que hay entre los dos expresados ríos, que lo dividen y servirán de linderos, con los fieles que comprehende; y mandó se pongan edictos para su provisión; y en cuanto al coste que tendrá concluir la iglesia con altar, vasos sagrados y demás necesario para su servicio; que don Domingo País haga su tasación e informe juntamente con el padre fray Justo Alvarado, si fuera de las limosnas que se le han hecho para lo trabajado, espera conseguir otras nuevas de aquella feligresía; remitiéndose para ello testimonio de este auto, del cual se pondrá otro en los libros de ambos curatos. Y así la proveyó, mandó y firmó Su Señoría Ilustrísima de que doy fe.- El Obispo.-Ante mí.- Nicolás de Herrera, notario mayor"s.

Esta erección de la antigua doctrina en parroquia permitió consolidar la autonomía de la villa de Pelarco, puesto que nunca se realizó en ella un acto fundacional explícito. En otras palabras, no existe en los registros históricos una fecha o documento que demuestre que la villa en cuestión haya sido formalmente fundada, por lo que, como señala el pelarquino Lautaro Vivar, "se reconoce como tal la [fecha de fundación] de la parroquia, como ocurre con casi todos los centros poblados de semejante origen. Además, [los pelarquinos] no deben haber sido muy letrados como para haberse preocupado de levantar un Acta de Fundación. Tenían asuntos más premiosos de que ocuparse, como era la supervivencia y la pacífica convivencia con los naturales, desplazados o asimilados" ${ }^{\prime \prime}$.

La nueva parroquia de San José de Pelarco, de la cual dependieron las viceparroquias de Cumpeo y San Rafael, inició ese mismo año (1787) la construcción de su iglesia en un terreno que prestó el hacendado Antonio Ovalle ${ }^{10}$.

\footnotetext{
${ }^{7}$ Vivar Encina, Lautaro, Historia de la aldea "San José de Pelarco", 1994, p. 2. Pedro Pablo de la Carrera y Dávila fue cura párroco de Talca desde febrero de 1762 hasta febrero de 1789, y fue quien puso óleo y crisma a Bernardo O’Higgins Riquelme. Opazo Maturana, Gustavo, Historia de Talca: 1742-1942, Imprenta Universitaria, Santiago, 1942, p. 209.

${ }^{8}$ Archivo de la secretaría arzobispal de Santiago de Chile, legajo X, nº 12, auto de erección de la parroquia de Pelarco, 17 de diciembre de 1787, en: Archivo del Arzobispado de Santiago.

${ }^{9}$ Vivar Encina, Lautaro, Op. cit., p. 3.

${ }^{10}$ González Cruchaga, Carlos, Op. cit., p. 178.
} 


\section{La primera iglesia parroquial y sus enseres}

El primer libro de fábrica de la parroquia inicia el registro de sus cuentas en 1788, es decir, un año más tarde de su fundación como tal. Sin embargo, por la lectura del detalle de los gastos se deduce que la construcción y amoblado de la iglesia aún distaba mucho de estar acabada: nudos de gonces o bisagras; clavos gemales; puertas para la sacristía y la entrada principal; hechura del corredor; revocado de los muros de la iglesia, sacristía, corredor y cuarto de los sacerdotes; y ventanas y mesa para el altar, son algunos de los gastos importantes realizados ese año. Todo esto, más otros expendios menores -como la compra de charqui y la paga de los carpinteros, albañiles y peones, por ejemplo- dieron la suma de doscientos noventa pesos, seis reales y tres cuartillos ${ }^{11}$.

Luego de seis años de inexplicable vacío de información, vuelven los registros de cuentas en 1794. Al parecer, para entonces ya estaba concluida la obra edilicia -con excepción de la torre, levantada ese año con 700 adobes, y la instalación de vigas en ésta y en las gradas, por un costo total de 18 pesos y 2 reales. Los gastos se concentraron mayoritariamente en ornamentación y elementos necesarios para la celebración de la Santa Misa, tales como "manteles de bretaña fina, randa y puntos para el altar de la parroquia"; una pila para el agua bendita y otra para las manos, con dos paños para secar; una cruz; dos confesionarios y un arpa ${ }^{12}$. Ese año, además, se hicieron dos gastos extraordinarios: se trastejó el techo, dañado por el "huracán de viento del cual se levantaron muchas tejas", y se mandó terraplenar el suelo de la iglesia, cubriéndose aparentemente con ladrillos de fabricación local ${ }^{13}$.

Hacia 1806, la parroquia ya contaba con un mobiliario y ornamentación bastante completo e incluso renovado. En el "Inventario de los muebles, alhajas, vasos y vestiduras sagradas de la iglesia y sacristía de la parroquia de San José de Pelarco" realizado por el Vicario de San Agustín de Talca, se apunta la adquisición de un nuevo altar o retablo, de aproximadamente ocho metros de alto y con dos atriles, uno con perfiles dorados y el otro sin pintar; una mesa de altar con frontal de papel; un púlpito "nuevo y muy decente" y dos confesionarios nuevos ${ }^{14}$. Respecto a los elementos ornamentales y funcionales para celebrar la Santa Misa la iglesia disponía, entre otras cosas, de una pequeña imagen de la Purísima con corona de plata, un San José con manto de brocato rosado y un Cristo de yeso en la cruz, de 40 centímetros; seis blandones (candeleros) de cobre; un centellero (candelabro) con cuatro candilejas; dos campanillas de cobre; una alfombra de pelo nueva y otra vieja; un misal nuevo y otro viejo; una custodia de plata de $45 \mathrm{~cm}$., aproximadamente; un copón y dos cáliz de plata nuevos; un par nuevo y uno antiguo de vinajeras y sus platillos, todo de plata; un portaviático de plata; tres frasquitos de plata para la extremaunción, óleo y crisma, y tres de cristal para traer los santos óleos de Santiago. La riqueza y variedad de las telas, tanto para la indumentaria sacerdotal como para la ornamentación del altar, es

\footnotetext{
${ }^{11}$ Libro de fábrica de la parroquia de San José de Pelarco $n^{\circ} 1,1^{\circ}$ de diciembre de 1788 a 30 de noviembre de 1827 , fojas $1 \mathrm{v} . \mathrm{a} 2 \mathrm{v}$.

${ }^{12}$ Libro de fábrica de la parroquia de San José de Pelarco nº1, Op. cit., fojas 2r. y 3v. Bretaña es un tipo de tela; randa es el trabajo de encajes para decorar principalmente ropa blanca.

${ }^{13} \mathrm{Ibíd}$., foja 2r. Aunque no se explicita, en el libro se señala el apisonamiento y fabricación de ladrillos como un solo ítem, lo que induce a pensar que efectivamente los ladrillos serían destinados al suelo del templo.

${ }^{14} \mathrm{La}$ RAE define frontal como "paramento de sedas, metal u otra materia con que se adorna la parte delantera de la mesa de altar".
} 
un indicador más de las valiosas posesiones que la parroquia conservó desde muy temprano ${ }^{15}$.

Otro dato a considerar es que para entonces ya se habían instalado las campanas de la torre, que eran dos de treinta a cuarenta libras cada una ${ }^{16}$.

A todo lo anterior, deben agregarse otras adquisiciones realizadas a fines de 1806 por el párroco de Pelarco José Antonio Palacios. Entre éstas, se encuentra "una imagen de Nuestra Señora del Carmen con su gala muy decente, [con] el centro de brocato morado, y capa de delfina blanca de seda con gargantilla y zarcillos de piedra, y una guirnalda en la cabeza de flores de hilo de plata falsa", de 1,68 m. de alto y con el Niño Jesús en su mano. Además, una nueva imagen de San José de 1,26 m., vestido de tafetán amarillo y capa de seda verde, con el Niño a su lado; dos palias de mejicana rosada -una de ellas "con su paño de pontibi y melindre de plata"- ; una mesa cuadrada de un pie de alto, para poner la caldereta y campanillas; dos bancas de $2,5 \mathrm{~m}$. cada una; ocho sillas para el cuarto del sacerdote y otras funciones de la iglesia; y cuatro blandones de madera torneados con candilejas de hojalata ${ }^{17}$.

Un año más tarde, el mismo párroco apuntaba en el libro de fábrica: "considerando la necesidad que tenía esta parroquia de un campo santo, me he determinado hacerlo, y para esto compré tres mil quinientos adobes a cinco pesos el millar", junto con las piedras para los cimientos, las tejas, ladrillos y mano de obra, con un costo total de $\$ 22$ pesos y 16 reales. Éste fue el primer cementerio de Pelarco, y sólo a partir de entonces se estableció un registro de las defunciones, quedando en incógnita el lugar donde se habrían enterrado los cadáveres antes de 1807. También se construyó una cocina nueva, "pues se había de comer en el corredor, con grande peligro de quemarse la iglesia y con mucha incomodidad," la cual significó el desembolso de $\$ 2$ pesos $^{18}$.

\footnotetext{
${ }^{15}$ En 1806, el "Inventario de los muebles, alhajas, vasos y vestiduras sagradas de la iglesia y sacristía de la Parroquia de San José de Pelarco, que yo Don José Ignacio Cienfuegos, cura y vicario foráneo de la ciudad de San Agustín de Talca, he hecho, por comisión de el Ilustrísimo Señor Doctor Don Francisco José de Morán y Mendoza, dignísimo Obispo de esta Diócesis del Consejo de Su Majestad, en veinte y ocho días del mes de octubre del año de mil ochocientos y seis", enumera dos mangas nuevas de cruz, una negra con galón de oro falso y una blanca con galón de plata fina, y ambas con flecos de seda. También un frontal de melania rosada con galón de plata fina y otro de melania negra con galón falso de oro; dos tablas de manteles nuevos "de bretaña legítima" y otra de manteles viejos; cinco palias; dos cornualtares y cuatro corporales de holanda con miriñaques decorativos, todos nuevos; un corporal de bretaña; siete hijuelas cuadradas y siete redondas; tres purificadores de holanda; una capa de coro de brocatillo blanco de seda, con galón de plata y forro de sangalete rosado, y otra de melania negra con galón falso de oro, ambas nuevas; cuatro ornamentos para el altar, uno negro de melania, otro de mejicana azul con blanco, otro de damasco negro, y otro de brocatillo de seda blanca, nuevos; tres casullas, una rosada con franja de seda, otra de damasco verde con franja de oro falso, y otra de lustrina amarilla con franja de oro falso; dos cíngulos nuevos de cintas plateadas con rapacejo de hilo de plata y otros dos más antiguos; y dos albas nuevas de bretaña y una antigua. Libro de fábrica de la parroquia de San José de Pelarco nº , Op. cit., fojas 14v. a 15v.

Según la RAE, las mangas son "adornos de tela que, sobre unos aros y con forma de cilindro acabado en cono, cubre parte de la vara de la cruz de algunas parroquias". El galón suele utilizarse en los bordes de las telas de las vestiduras como adorno, a manera de cinta. La melania, al igual que el damasco, sangalete, brocato o brocatillo, bretaña, holanda, mejicana, lustrina y pontibi, son tipos de paños o telas. Palia se denomina el lienzo firme y cuadrado bajo el cual se extiende el corporal para decir misa, ambos sobre el cáliz; y para la limpieza de éste se utiliza el paño denominado purificador. Cornualtar es el lavabo para manos; la hijuela, el lienzo circular que cubre la hostia sobre la patena hasta el momento del ofertorio. Respecto a la vestimenta del sacerdote celebrante, el alba es la túnica de paño blanco que se ciñe a la cintura con el cíngulo (cordón de seda o lino) y sobre el cual se coloca la casulla, pieza de tela decorada, larga y con una obertura al centro para la cabeza.

${ }^{16}$ Libro de fábrica de la parroquia de San José de Pelarco n ${ }^{0} 1$, Op. cit., foja $15 \mathrm{v}$.

${ }^{17}$ Ibid., fojas $15 \mathrm{v}$. y $15 \mathrm{r}$.

${ }^{18}$ Ibid., foja $16 \mathrm{r}$.
} 
Con el tiempo, se fueron añadiendo nuevas adquisiciones a la lista de bienes de la iglesia. En 1807, por ejemplo, se compraron ocho sillas y dos banquetas de 2,5 m. cada una, mientras que al año siguiente se realizaron algunas reparaciones, como el suelo de ladrillos de las habitaciones de los sacerdotes, los corredores y el interior de la iglesia; el trastejado del techo, al parecer muy dañado tras el paso de cada invierno; y la excavación de un pozo para extraer agua potable ${ }^{19}$.

\section{La iglesia de Pelarco en la primera mitad del siglo XIX}

Los movimientos independentistas ocurridos en el país a partir de 1810 afectaron indiscutiblemente a la parroquia, pero de manera transitoria y en un grado moderado. En primer lugar, se omitieron las cuentas de entradas y salidas, restableciéndose a partir de 1812. Ese año -y quizás antes, pero no hay registros- se suspendieron momentáneamente las entradas "hasta tanto que se [determinara] por el Gobierno un fondo seguro de donde sacar el estipendio de los doce pesos [de] limosna" que tenía de pensión la iglesia para la aplicación de doce misas anuales ${ }^{20}$. Pero lo anterior no fue impedimento para que ésta continuara llevando un funcionamiento normal. En 1813, fue preciso reparar la torre y trastejar gran parte del techo de la iglesia, averiada por un temblor, trabajo realizado nuevamente en 1815 junto con el aumento de altura de la tapia de adobe que se había levantado en 1807 -que sin embargo volvió a derrumbarse en 1816- y el levante de medias aguas en todo el costado norte para construir tres nuevos cuartos y una caballeriza ${ }^{21}$. El primer cuarto se destinó a gallinero; el segundo a pajar y el tercero a bodega, todos los cuales fueron concluidos al año siguiente e importaron un costo total de $\$ 25$ pesos $^{22}$.

A diferencia de los enseres y ornamentos del templo, es escasísima la información que ha podido hallarse respecto a su estructura original. No obstante la mención de las bodegas, caballerizas y cuartos para los sacerdotes, no se explicita su ubicación ni distribución, así como tampoco se detallan las dimensiones de la iglesia y su sacristía. Recién en 1818 se mencionan por primera vez las medidas básicas, en el inventario levantado por el Licenciado y presbítero Juan Bautista Zúñiga, por orden del canónigo y Gobernador José Ignacio Cienfuegos. Éstas eran "treinta y cinco varas y una tercia de largo, y ocho varas de ancho", es decir, 29,68 m. de largo por 6,72 de ancho. Para entonces, el techo no se encontraba en muy buenas condiciones, mientras que el campanario estaba "cuasi arruinado" y la mayor de sus campanas se hallaba rota. Se sabe que el edificio, construido en adobe, con suelo de ladrillo y vigas de soporte para el techo y torre campanario, contaba con "una puerta al frente y otra al costado, con chapa y cerrojo", ambas de madera. De las ventanas se desconoce la cantidad, la altura y su ubicación, a excepción de "una ventana alta que cae al altar"23.

En el mismo inventario citado se encuentra el detalle del resto de la construcción, bajo el rótulo "Vivienda para los curas". Ésta consistía en una casa de adobe y con techo de tejas, con dos cuartos además de la antigua sacristía, que ahora se utilizaba como habitación. También se mencionan los tres cuartos para despensa y gallinero que se

\footnotetext{
${ }^{19}$ Libro de fábrica de la parroquia de San José de Pelarco $\mathrm{n}^{\mathrm{o}} 1$, Op. cit., fojas 16v. y 17r.

${ }^{20}$ Ibíd., foja $20 \mathrm{r}$.

${ }^{21}$ Ibid., fojas 17r., 21r., 25r. y 27v.

${ }^{22}$ Ibid., foja $27 \mathrm{v}$.

${ }^{23}$ Libro de fábrica de la parroquia de San José de Pelarco n ${ }^{\circ} 1$, Op. cit., foja 29v.
} 
describieron más arriba, así como la caballeriza ${ }^{24}$.

A fines de 1821 volvió a repararse la torre campanario y se trastejaron quinientas tejas, trabajo que se prosiguió al año siguiente, con la adquisición de otras cuatrocientas fabricadas en Talca. También se enladrilló de nuevo toda la iglesia. En 1823, los gastos se concentraron en la reparación y embellecimiento del altar: en octubre se levantó un tabique -se ignora exactamente en qué parte del altar-, se entabló y se repusieron muchas molduras que faltaban, trabajos en los cuales se desembolsaron $\$ 35$ pesos y 5 reales ${ }^{25}$.

Nueve años más tarde, volvían a cambiarse seiscientas tejas del techo de la iglesia, y en 1848 se realizó un trastejado completo. En esa época también se invirtieron \$104 pesos "en doscientos cincuenta tablas para [el] entablado de la iglesia, su labranza, enclavadura, clavos, cornisa y en [la] atención de [los] maestros todo el tiempo del trabajo." ${ }^{26}$ Otro desembolso importante fue el realizado en 1851, donde se destinaron $\$ 100$ pesos a la reparación de la casa parroquial, "que amenazaba ruina; [del] techo y paredes de la iglesia y una refacción completa de todo lo que estaba malo"27.

Como puede observarse tras lo relatado hasta ahora, desde los inicios de la construcción de la iglesia hasta mediados del siglo XIX, la parroquia de San José de Pelarco debió realizar constantes y significativos gastos extraordinarios, pues aun estando terminado el edificio principal, fueron siendo necesarias otras dependencias, como las habitaciones para los sacerdotes y misioneros, las despensas, caballerizas y gallineros, además del camposanto. Por otro lado, según se deduce de los registros en los libros de fábrica del período aludido, el duro clima invernal de la zona solía causar daños de distinta gravedad, siendo los más frecuentes el menoscabo del tejado y de las tapias de adobe.

\section{1855: La traslación de la parroquia y su nueva iglesia}

La ubicación geográfica de la iglesia de Pelarco -tres leguas más al poniente de su localización actual- presentaba varios inconvenientes. En primer lugar, el terreno seguía siendo de Antonio Ovalle, dueño de la hacienda en la cual estaba emplazada, y además de ser estrecho -unos $63 \mathrm{~m}$. de largo, aproximadamente- no contaba con más agua potable que la que el hacendado quisiera disponer, cantidad que siempre se hacía escasa para las necesidades de la parroquia y sus dependencias. Por otra parte, el número de habitantes cercanos a la iglesia se reducía a seis inquilinos y los dueños de la hacienda, mientras que el resto de los feligreses pertenecientes al curato (alrededor de 11.400 personas) debían sortear diversas dificultades para poder llegar, como la aridez y sequía de los caminos en verano y las inundaciones invernales por los desbordes de los esteros de Pelarco y La Capilla. Por último, los constantes desórdenes provocados por los inquilinos y vecinos reunidos en chinganas y fiestas alteraban la tranquilidad del templo, siéndole al párroco imposible poner orden por no ser el propietario del terreno. A estos inconvenientes, debe añadirse el deterioro de la construcción de la iglesia y casa parroquial, además de la cercanía en que se hallaba el cementerio de éstas.

\footnotetext{
${ }^{24}$ Ibíd., foja 30r.

${ }^{25}$ Ibid., fojas 36r., 38v., 40r. y 42r.

${ }^{26}$ Libro de fábrica de la parroquia de San José de Pelarco no 2, 4 de diciembre de 1847 a 19 de junio de 1861, fojas 4v. y 16v. ${ }^{27}$ Ibid., foja 19 r.
} 
Por todo lo anterior, ante el ofrecimiento de diez cuadras de terreno que donaba el vecino de Pelarco José Santos Besoaín, el párroco José Domingo Leal no dudó en solicitar al Arzobispo de Santiago la traslación de la iglesia y casa parroquial a las inmediaciones del estero Pangui, tres leguas (cerca de 17 kilómetros) más al oriente. También le proponía comprar otras quince cuadras más con las erogaciones que habían prometido algunos vecinos. En su nuevo destino, la iglesia quedaría mucho más cerca de los dos centros más poblados del curato, a saber, El Manzano y El Rincón. Esta petición, que contó con el apoyo del Alcalde de Talca Cayetano Astaburuaga, fue bien acogida por el Arzobispado capitalino, y el 7 de julio de 1855 se dictó el siguiente decreto:

"Santiago julio 7 de 1855.

Se autoriza al cura y vicario de la parroquia de Pelarco para que pueda proceder a la construcción de una iglesia a las inmediaciones del estero de Pangui en el terreno que propone en su solicitud de fojas uno a donde deberá trasladarse el servicio parroquial tan pronto como se halle expedita la dicha iglesia. Se encarga al mencionado cura que proceda a hacer otorgar los correspondientes instrumentos de donación de los terrenos ofrecidos y de compra de los que deben adquirirse con la colecta de los vecinos a que hace referencia la misma solicitud, e igualmente a formar el correspondiente presupuesto del costo de los edificios para solicitar del Supremo Gobierno los subsidios necesarios.

El Arzobispo de Santiago [Rafael Valentín Valdivieso].

Astorga, pro-secretario"28.

El presupuesto para la construcción de esta nueva iglesia, presentado por José Benito Mannheim (ingeniero civil alemán radicado en Talca), contemplaba diversos materiales, tales como 40 vigas de madera de 7,14 m. de largo y 6 a 8 pulgadas de grueso; pilares de 11,76 m. de alto y 0,28 de grueso; ladrillos para el pavimento de corredores y gradas; maderas para las hojas de las puertas y capiteles; piedras para las gradas; clavos; coligue; etcétera. El costo total se estimaba en $\$ 9.996$ pesos $^{29}$.

Como la iglesia y casa parroquial se trasladarían varios kilómetros al oriente, el párroco Leal pidió "permiso para mudar el cementerio adjunto en que se ha de construir la iglesia parroquial, haciendo de éste la exhumación de los cadáveres que contiene y demolerlo para evitar fraudes" 30 . Se desconoce la respuesta a esta petición, mas es de suponer que fue bien acogida si se pretendía evitar el posible saqueo de las tumbas.

A mediados de 1857, ya estaban concluidas las casas parroquiales. La construcción, realizada en adobes, formaba un claustro cerrado y rodeado por corredores internos y externos, y medía en total 138 varas -es decir, 115,92 m. ${ }^{31}$ En uno de sus cañones se instaló una capilla provisoria para usar mientras se continuaba con los trabajos de la iglesia. En cuanto a ésta, se había proyectado un edifico de estilo neogótico con una nave central de $46 \mathrm{~m}$. en su claro largo por 12,75 en su claro ancho, con dos pequeñas habitaciones a los costados del presbiterio: una para bautisterio y otra para sacristía, cada una de 8,73 m. de claro largo. En el altar mayor, una rotunda construida saliente al cañón, con forma de medio octógono regular. Los muros de la iglesia serían de

\footnotetext{
${ }^{28}$ Archivo de la secretaría arzobispal de Santiago de Chile, legajo 24, n 68, expediente sobre la traslación de la iglesia parroquial de Pelarco. 1855-1885, fojas 4r. y 5v., en: Archivo del Arzobispado de Santiago.

${ }_{29}$ Ibíd., fojas 6v. y $6 \mathrm{r}$.

${ }^{30}$ Ibid., foja $8 \mathrm{v}$.

${ }^{31}$ Ibid., foja $15 \mathrm{v}$.
} 
1,55 m. de grosor y 8,56 de altitud, construidos con ladrillo y barro -a excepción de los arcos de ventanas y tragaluces, que serían de cal y ladrillo-, todo reforzado con marbones de ladrillo y barro. Por último, tendría una torre campanario de madera, también neogótica, alcanzando una altura de $16,8 \mathrm{~m} \cdot{ }^{32}$

Para todas estas faenas, se contó con fondos del Gobierno -quien aportó \$1.500 pesos-, las erogaciones de los particulares de la zona y las entradas de la parroquia. Sin embargo, estas sumas no fueron suficientes para cubrir todos los gastos, y a diez años del inicio de la construcción el párroco le informaba al Arzobispo de Santiago que los fondos se encontraban agotados. Los muros ya alcanzaban los ocho metros de altura y era indispensable amarrarlos con el enmaderado y techumbre, a fin de preservarlos de la intemperie y evitar su desplome. En estas circunstancias, los agrimensores generales Bernardo Fuenzalida y José Antonio Silva Vergara realizaron un nuevo presupuesto, el cual superaba las cifras del que había presentado inicialmente Mannheim. Según sus cálculos, terminar los muros, instalar los vitrales, techar el templo y construir la torre campanario tendría un costo de $\$ 4.238$ pesos y 67 centavos $^{33}$.

Luego de algunos meses de intercambio de correspondencia entre el párroco de Pelarco, el Intendente de Talca, el Arzobispo de Santiago y el Ministro de Culto, a principios de 1868 el Gobierno otorgó la suma necesaria para terminar la construcción de la iglesia.

Frente al templo, y en los terrenos que pertenecían a la parroquia, se construyó una plaza. Hacia 1873, el padre José Domingo Leal se encargó de cultivar un jardín en ella, permitiendo la instalación de una ramada en una de sus esquinas y cercándola en toda su extensión. Esto último provocó la molestia y recelo por parte de algunos vecinos, quienes en 1885 apelaron a las autoridades civiles para que se abriera la plaza, la cual consideraban de dominio público. Luego de algún tiempo, la cerca finalmente se retiró.

El destino de la iglesia y casa parroquial originales es desconocido. Se sabe que al momento de la traslación, esta última estaba en muy mal estado: "no me atrevo a habitar las casas viejas de esta parroquia porque están desmoronándose", le escribía Leal al Arzobispo en junio de 1857. La iglesia también presentaba algunos daños, como se dijo más arriba, y al encontrarse en los terrenos de Antonio Ovalle, la construcción quedó a disposición de su voluntad. Esto mismo significó un conflicto que llegó hasta el Arzobispado de Santiago, pues al enterarse que el hacendado había comenzado a guardar el trigo en la antigua iglesia, el párroco de Pelarco se lo hizo saber a las autoridades eclesiásticas. El Arzobispo Rafael Valentín Valdivieso le escribió a Ovalle para que la desocupara inmediatamente, previniéndole que de lo contrario sería excomulgado "por violar la inmunidad de un lugar sagrado", orden que fue acatada por el aludido sin pasar a mayores consecuencias. Es de suponer que ambas construcciones -la iglesia original y su casa parroquial- acabaron por desplomarse con el tiempo, pues hoy no queda rastro de ellas ${ }^{34}$.

\footnotetext{
${ }^{32}$ Ibíd., foja 20v. Actualmente, la altura de la iglesia desde el suelo hasta la base de la cruz de la torre campanario es de 21,5 mts., lo que induce a pensar que las medidas fueron modificadas en el momento de la construcción, o bien se aumentó la altura de la torre campanario tras su reconstrucción por los efectos sísmicos.

${ }^{33}$ Archivo de la secretaría arzobispal de Santiago de Chile, legajo 24, no 68, Op. cit., foja 20v.

${ }^{34}$ Ibíd., legajo 39, n 15, Don Antonio Ovalle. Profanación de la antigua iglesia de Pelarco, 1862, foja 2v., en: Archivo del Arzobispado de Santiago.
} 
En cuanto a los gastos extraordinarios del nuevo templo, en la segunda mitad del siglo XIX mermaron de manera drástica, siendo mucho más esporádicos. Se sabe que fue adquirido un nuevo órgano -conservado actualmente en la oficina parroquial-, el cual requería un ajuste de vez en cuando. Otros gastos excepcionales consistieron en el blanqueamiento de la iglesia, la reparación del tejado y el altar, y la compra de libros para el registro de bautismos, matrimonios y defunciones. Los gastos ordinarios continuaron también sin alteraciones, concentrándose principalmente en el salario del sacristán, el pago a la lavandera de las ropas y manteles de la iglesia, aceite para la lámpara, cera y velas de cebo, hostias y vino.

El 22 de diciembre de 1891, el Ministerio del Interior promulgó un decreto que establecía la creación de la Municipalidad de Pelarco, adquiriendo el rango de comuna $^{35}$.

\section{La iglesia de Pelarco y el registro sísmico a lo largo del siglo XX}

Aunque la palabra Maule en mapudungun quiere decir "río lluvioso en forma de remolino", es una zona reconocida por su regular actividad sísmica. En los libros de fábrica de la parroquia de San José de Pelarco correspondientes al siglo XIX no se han encontrado referencias a daños por terremotos; sólo en 1813 se habla de la reparación de la torre campanario producto de un temblor -que, por lo demás, no se sabe si ocurrió ese mismo año o el anterior. Esto no implica en modo alguno que no haya habido fuertes movimientos telúricos a lo largo de 1800; baste considerar el terremoto del 20 de febrero de 1835, que si bien tuvo su epicentro en Concepción, dejó grandes perjuicios y numerosas víctimas en Talcahuano, Chillán, Constitución, Talca y Cauquenes, y en general en todas las ciudades del valle central al sur de Rancagua ${ }^{36}$.

Respecto al siglo $\mathrm{XX}$, en cambio, hay registros de los daños provocados en la iglesia por tres grandes terremotos: el del $1^{\circ}$ de diciembre de 1928, 3 de marzo de 1985 y 27 de febrero de $2010^{37}$.

El sismo de 1928, de 8,0 grados en escala de Richter, tuvo su epicentro en Talca, ciudad que quedó seriamente perjudicada junto con Constitución, "causando también algunos daños desde Valparaíso a Concepción. El número de muertos llegó a 108 en Talca, 67 en Constitución y 50 en los pueblos y aldeas, sumando un total de $225^{\prime \prime 38}$. Según El Mercurio de Santiago, el terremoto se percibió desde Antofagasta a Puerto Montt e incluso Buenos Aires, con una sensibilidad aproximada de $2.000 \mathrm{~km}^{39}$.

No se conocen con exactitud los daños provocados en la iglesia de Pelarco, excepto el derrumbamiento de la torre campanario, la cual fue reemplazada por otra de material más ligero (tabiques de madera revestidos de zinc), y es muy probable que sea la que se mantiene hasta hoy en día ${ }^{40}$. Pero si el epicentro fue a tan sólo 26 kilómetros

\footnotetext{
${ }^{35}$ Labra, Álvaro, Las primeras capillas e iglesias (con la categoría de Monumento Histórico y/o Zona Típica) en la Región del Maule: una mirada sistémica, FONDART, Talca, 2010, p. 93.

${ }^{36}$ Sanhueza Torrealba, Simón, Estudio de los daños del terremoto de Talca de 1928, memoria para optar al título de ingeniero civil, Universidad de Chile, Santiago, 2002, p. 18.

${ }^{37}$ De los posibles efectos negativos del terremoto del 22 de mayo de 1960 no hay referencias en las fuentes consultadas.

${ }^{38}$ Sanhueza Torrealba, Simón, Op. cit., p. 19.

${ }^{39}$ El Mercurio de Santiago, 4 de diciembre de 1928.

40 Tapia, Marisol, "La iglesia Patrimonio Histórico de Pelarco", jueves, $1^{\text {o }}$ de octubre de 2009, en: http://www. canalpatrimonio.com/es/noticias/?iddoc=53993 [Consulta: 6 de diciembre 2011].
} 
al suroeste, es posible imaginar cuán perjudicada pudo quedar esta construcción, teniendo en cuenta que en Talca "varias iglesias resultaron destruidas o debieron ser demolidas, como la Catedral, Santo Domingo, San Francisco, San Juan de Dios, la iglesia de San Luis [y] la iglesia de la población oriente" -según relataba el diario La Mañana de Talca ${ }^{41}$.

El mismo mes del terremoto, los fieles realizaron una colecta para la reconstrucción de la iglesia y casa parroquial, recaudando un total de \$114 pesos. A lo largo del año siguiente continuaron las donaciones: \$200 pesos de los socios de San José de Pelarco, \$6.400 de las colectas del padre Juan González, \$2.000 del Obispo de Talca, \$951 de distintas colectas de los fieles, $\$ 503$ de dos fiestas de beneficencia, $\$ 600$ del particular Alejando Bezanilla y \$500 del particular Froilán Valenzuela.

A diferencia del terremoto de 1928, sí se sabe con detalle cuáles fueron los daños estructurales provocados por el de 1985 (de 8, $0^{\circ} \mathrm{M}_{\mathrm{w}}$ ), gracias al informe realizado por los arquitectos Alberto García Huidobro y Patricio Durán y el ingeniero civil Renato Guerra: los contrafuertes se agrietaron y algunos se separaron de los muros de la iglesia; la pintura y piezas de madera de las bóvedas del cielo falso quedaron en mal estado, al igual que las sacristías; la cornisa superior (de albañilería de ladrillo) quedó suelta y con peligro de desprenderse; y el muro posterior también se agrietó ${ }^{42}$.

Aparentemente, el Obispado de Talca era de la opinión de demoler el ruinoso edificio para construir otro "más liviano, asísmico, funcional y moderno", según las palabras de Lautaro Vivar. Ante esta noticia, los vecinos de Pelarco se organizaron para contribuir una vez más con su aporte monetario y su trabajo, a fin de rescatar el templo antes de que fuera demasiado tarde. Como los daños eran cuantiosos, se le dio prioridad a la reparación de aquellos que tenían mayor urgencia: "reforzamientos, renovación de las planchas de zinc, hierros que uniesen los muros de la capilla del lado norte", reemplazo de la cubierta de los transeptos por una achaflanada, pintura de los muros internos -costeada por Josefina Echenique de Correa- y arreglo de la techumbre y grietas mayores -costeado por Inés Barros Donoso de Ávila ${ }^{43}$.

Aunque no hay registros que lo corroboren, diversos testigos, antiguos habitantes de Pelarco, coinciden en que en esta época se botó la parte surponiente de la casa parroquial, donde se encontraba la oficina, el salón, el comedor y la habitación del sacerdote. Los motivos apuntaban, de acuerdo al testimonio de los pelarquinos, a las malas condiciones de la construcción. Se conservó la parte nororiente en forma de L, como puede apreciarse hoy en día, donde se hallaban las habitaciones destinadas a los misioneros y otros fines. En el espacio que dejó esta demolición, se levantó una casa de concreto para la oficina parroquial y vivienda del sacerdote.

Pero a pesar de todos estos arreglos y la colaboración entusiasta de los feligreses, el templo distaba mucho de estar plenamente restaurado. Por eso, un grupo de vecinos decidió reunirse en 1990 para formar el comité pro restauración de la iglesia de

\footnotetext{
${ }^{41}$ La Mañana, Talca, $1^{\circ}$ de diciembre de 1928.

${ }^{42}$ Informe de los daños estructurales de la iglesia de San José de Pelarco realizado por los arquitectos Alberto García Huidobro y Patricio Durán y el ingeniero civil Renato Guerra, Talca, 28 de marzo de 1989, en: Archivo del Obispado de Talca.

${ }^{43}$ Vivar Encina, Lautaro, Op. cit., p. 4, y http:/ / www.pelarco.org/marco_central_inferior_restauracion.swf [Consulta: 21 de diciembre 2011]
} 
Pelarco (CRIP), que fue presidido por el párroco de entonces, el padre Gilberto Rojas L., e integrado por Lautaro Vivar E. (secretario), Sara Carrasco A. (tesorera), Jaime Lavín M., Jorge Morales Q. y Carlos Verdugo P. (directores). Además, contó con el apoyo del Obispado de Talca.

Este comité presentó su proyecto de restauración al Fondo Nacional de la Cultura y las Artes (FONDART), considerando seis puntos principales a componer: la torre, el transepto posterior oriente y poniente, los contrafuertes, la cadena general de amarre y la cubierta. Para esto, se estimó un costo total promedio de 25 millones de pesos ${ }^{44}$. El proyecto obtuvo el mayor monto nacional, es decir, 10 millones de pesos, y contó con la participación activa de los integrantes de la Office Culturel de Cluny (OCC, París), coordinada por el arquitecto francés Thierry Lévy, además del trabajo del arquitecto chileno Patricio Gross y del ingeniero calculista Sergio Rojo.

Uno de los primeros trabajos realizados con los fondos obtenidos fue retirar los revoques de los muros internos para dejar el ladrillo a la vista. Las capillas laterales se remozaron y reforzaron con tirantes de hierro. Se instalaron asimismo lámparas de hierro forjado en forma de aros para mejorar la iluminación interior. Además, se recompuso la bóveda de madera de álamo y se pintó de nuevo. Los vidrios coloridos de las ventanas fueron repuestos, mientras que las antiguas imágenes de la Virgen del Carmen y de San José y el Niño fueron prolijamente restauradas por el profesional Osvaldo Pincheira.

El piso del campanario mantuvo sus ladrillos, y en el presbiterio se colocaron ladrillos nuevos combinados con madera ${ }^{45}$.

Los trabajos se terminaron en 1993, y la nueva imagen de la iglesia de San José de Pelarco, completamente restaurada, constituyó uno de los principales motivos para impulsar a las autoridades de la comuna a proponer al Gobierno su nombramiento como monumento nacional ${ }^{46}$. Así fue como el académico de Villa Alegre Jaime González Colville y la entonces alcaldesa de Pelarco, Raquel Argandoña, con el apoyo del Obispado de Talca y de toda la comunidad pelarquina, iniciaron los trámites requeridos a partir de agosto de 2001. La solicitud tuvo una buena acogida en el Consejo de Monumentos Nacionales, y luego de algunos meses se decretó lo siguiente:

\footnotetext{
44 "Restauración iglesia de Pelarco. Análisis de costos de construcción", en: Archivo del Obispado de Talca.

${ }^{45} \mathrm{http}$ :/ / www.pelarco.org/marco_central_inferior_restauracion.swf [Consultado el 21 de diciembre de 2011].

46 "Son monumentos nacionales y quedan bajo la tuición y protección del Estado, los lugares, ruinas, construcciones u objetos de carácter histórico o artístico; los enterratorios o cementerios u otros restos de los aborígenes, las piezas u objetos antropo-arqueológicos, paleontológicos o de formación natural, que existan bajo o sobre la superficie del territorio nacional o en la plataforma submarina de sus aguas jurisdiccionales y cuya conservación interesa a la historia, al arte o a la ciencia; los santuarios de la naturaleza; los monumentos, estatuas, columnas, pirámides, fuentes, placas, coronas, inscripciones y, en general, los objetos que estén destinados a permanecer en un sitio público, con carácter conmemorativo." Ley n ${ }^{\circ} 17.288$ de Monumentos Nacionales, art. $1^{\circ}$. Dentro de los denominados Monumentos Nacionales, existen las siguientes categorías: Monumento Histórico, Monumento Arqueológico, Monumento Público, Zona Típica y Santuario de la Naturaleza.
} 
"Santiago, 6 de marzo de 2002.

Considerando:

Que el templo parroquial San José de Pelarco data de 1787, siendo la primera parroquia de la zona y [que] se reconoce como uno de los templos más antiguos de la Región del Maule.

Que este templo es un ejemplo de la arquitectura de los siglos XVIII y XIX, en donde la edificación de ladrillo era un arte de nobles características, ejemplo de lo cual son el conjunto de arcos y ventanas y puertas, como también las columnas y muros laterales, que incluyen un contrafuerte de ladrillo, elemento estructural de los templos románicos, presenta en su interior una bóveda gótica de madera y hermosos vitrales multicolores que otorgan luminosidad al recinto, $\mathrm{y}$ visto:

Lo dispuesto en la Ley n ${ }^{\circ} 17.288$ de 1970; acuerdo de sesión de 02 de enero de 2002 del Consejo de Monumentos Nacionales; Decreto Supremo nº 19 de 2001 del Ministerio Secretaría General de la Presidencia; Ord. N 680 de Secretaría del Consejo de Monumentos Nacionales de 25 de febrero de 2002; documentos de la Alcaldesa de Pelarco de 30 de agosto y 12 de noviembre, ambos de 2001; Resolución n520 de 1996 de la Contraloría General de la República; y los artículos 32 nº y 35 de la Constitución Política de la República de Chile,

Decreto:

Artículo Único: declárase Monumento Histórico el templo parroquial San José de Pelarco, Comuna de Pelarco, Provincia de Talca, VII Región del Maule, incluyendo el sector ubicado en la calle Domingo Leal s/n, entre las calles Camino de Cintura y San Pedro, delimitado por el polígono A,B,C,D,E,F,A, según se indica en el plano adjunto, que forma parte del presente decreto.

Anótese y publíquese por orden del Presidente de la República.

Mariana Aylwin Oyarzún, Ministra de Educación" ${ }^{\prime 7}$.

El terremoto de la madrugada del 27 de febrero de 2010 (de 8,8 $8^{\circ} \mathrm{M}_{\mathrm{w}}$ ) volvió a perjudicar seriamente la centenaria construcción. A solicitud del Obispado de Talca, el consultor e ingeniero civil Juan Mendoza V. realizó entre mayo y agosto del mismo año una inspección y completo informe acerca de los daños estructurales de la iglesia y oficinas parroquiales. De acuerdo a dicho informe, la estructura de la iglesia -de albañilería gravitacional- había disminuido su capacidad sismorresistente de manera sustantiva. Los contrafuertes nuevamente se desprendieron, al igual que parte de los muros y dinteles. La torre campanario se inclinó de forma notoria, peligrando su desplome. Además de estos daños estructurales hubo otros menores, como en el sistema de cielo, producto de la acumulación de material, y en ciertos elementos ornamentales, como las cornisas de albañilería.

La antigua casa parroquial de adobe también sufrió daños estructurales: grietas diagonales y pequeñas fisuras horizontales en los muros, sobre todo en el encuentro de éstos por la pérdida de trabazón; daños en los corredores por la inclinación de los postes de madera y desprendimiento de material, entre otros ${ }^{48}$.

\footnotetext{
${ }^{47}$ Decreto de erección de la iglesia de San José de Pelarco a Monumento Nacional, Santiago, 6 de marzo de 2002, en: Archivo del Obispado de Talca.

${ }^{48}$ Mendoza V., Juan, "Informe revisión estructural sismo de 27 de febrero de 2010. Parroquia San José de Pelarco", mayo 2010, e "Informe revisión estructural sismo de 27 de febrero de 2010. Salones y oficinas iglesia de Pelarco," septiembre 2010, en: Archivo del Obispado de Talca.
} 
Con estos antecedentes, el Consejo de Monumentos Nacionales solicitó la aplicación de ciertas medidas de emergencia, tales como el cubrimiento de los sectores expuestos y el desmonte de los materiales y elementos con peligro de colapso ${ }^{49}$. Asimismo, se retiraron todas las imágenes religiosas y objetos ornamentales e instrumentales, guardándose a la espera de su restauración. Ante la prohibición de usar el edificio, se instaló una carpa provisoria al costado, donde se celebra la Santa Misa y se imparten los sacramentos hasta hoy día. En febrero de 2011, esta entidad volvió a aprobar otras medidas de precaución: el apuntalamiento de seis contrafuertes en el sector norte, el desmontaje de otros seis en el sector sur, la instalación de un revestimiento de fachada sobre las áreas vaciadas, sobre el tímpano y campanario de la iglesia, la reparación y reposición de planchas de sistemas de cubiertas y protecciones hídricas, y en general el desmontaje de todo tipo de material que pudiese desplomarse ${ }^{50}$.

\section{La iglesia de Pelarco, su pasado y proyecciones}

Vista la antigüedad e importancia arquitectónica de la iglesia y casa parroquial de San José de Pelarco en los capítulos anteriores, no deja de llamar la atención la escasez de fuentes historiográficas relativas a sus inicios y desarrollo hasta nuestros días.

Después de las parroquias de Huenchullamí, Curepto (antigua Longocura) y La Merced de Talca, la de Pelarco es una de las más antiguas de la provincia de Talca ${ }^{51}$, hecho que por sí solo legitima cualquier intento por rescatar su templo del olvido y el deterioro que el tiempo y los sismos se han encargado de provocar.

Pero a esta antigüedad debe agregarse otro valor, a saber, el de su original e imponente arquitectura. Como ya se dijo, no hay registros que describan cómo fue la primera iglesia -salvo sus medidas y materiales de construcción-, pero la actual es un interesante exponente del neogótico en Chile, cuya riqueza estética como su carácter especial explica en cierto grado el ahínco de sus feligreses por preservarla y restaurarla cada vez que ha sido preciso. Por otra parte, el archivo parroquial es una fuente de enorme valor histórico y demográfico, pues da cuenta del desarrollo de la comunidad desde sus orígenes como parroquia a través de sus libros de fábrica, bautismos, matrimonios y defunciones. Por esto, urge mejorar las condiciones en las que se encuentra, a fin de preservar tan preciados antecedentes.

Los daños superficiales y estructurales del templo tras el terremoto del 27 de febrero de 2010 son cuantiosos, y prueba de ello es la orden de no ocupación que dictó el Consejo de Monumentos Nacionales. Su restauración es apremiante, no sólo -repetimos- por su antigua data, sino también por tratarse de una construcción emblemática de la zona del Maule, parte de la identidad de los habitantes de Pelarco, de reconocida originalidad arquitectónica y de un valor patrimonial incuestionable.

\footnotetext{
${ }^{49}$ Carta de Nelson Gaete González, coordinador regional del Consejo de Monumentos Nacionales, a Monseñor Horacio Valenzuela, Obispo de Talca, Talca, 21 de julio de 2010, en: Archivo del Obispado de Talca.

${ }^{50}$ Carta de Emilio de la Cerda Errázuriz, secretario ejecutivo del Consejo de Monumentos Nacionales, a María Elisa Díaz, secretaria ejecutiva de la Comisión Diocesana de Reconstrucción del Obispado de Talca, Santiago, 18 de octubre de 2011, en: Archivo del Obispado de Talca.

${ }^{51}$ Labra, Álvaro, Op. cit., p. 93.
} 
Como lo indica la misma Ley $\mathrm{n}^{\circ} 17.288$ de Monumentos Nacionales en su artículo primero, éstos son elementos "cuya conservación interesa a la historia, al arte [y] a la ciencia". Permitir su exterminio significaría perder una pequeña parte de nuestra identidad como país, y consciente de esto, el actual Gobierno, por medio del programa Puesta en Valor del Patrimonio del Ministerio de Obras Públicas, ha hecho un llamado a arquitectos y constructoras para concursar por fondos para su restauración ${ }^{52}$.

\section{Imágenes}

1. Mapa de la ubicación aproximada de la antigua y actual iglesia de San José de Pelarco $^{53}$

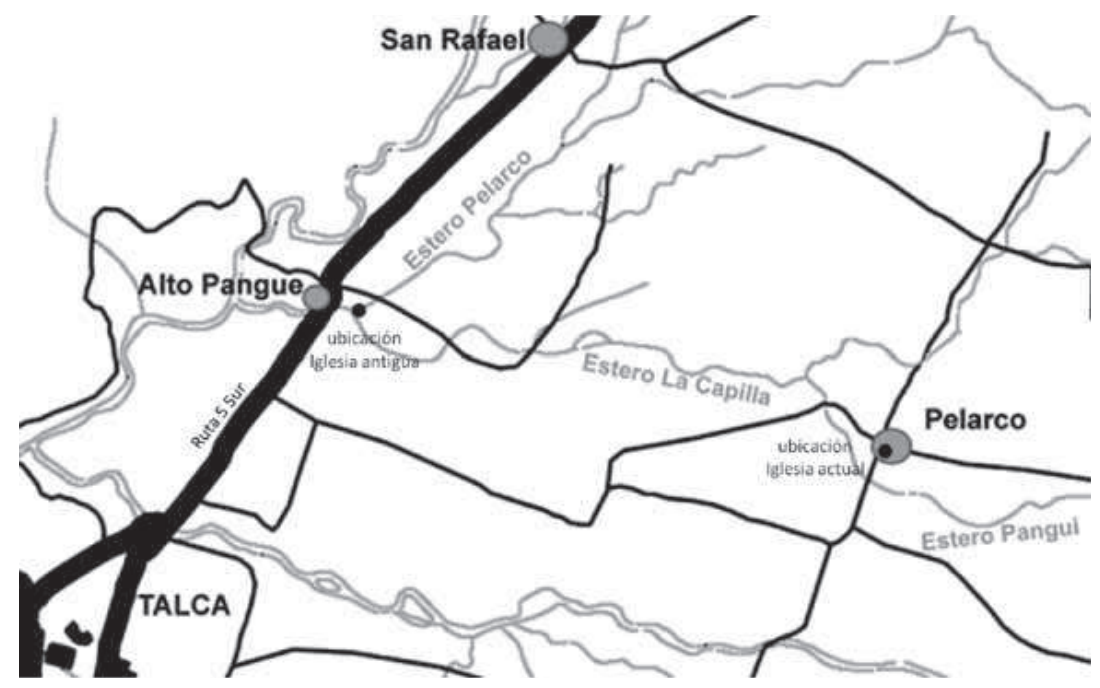

2. Planta de la iglesia y casa parroquial actual y su modificación (abajo)

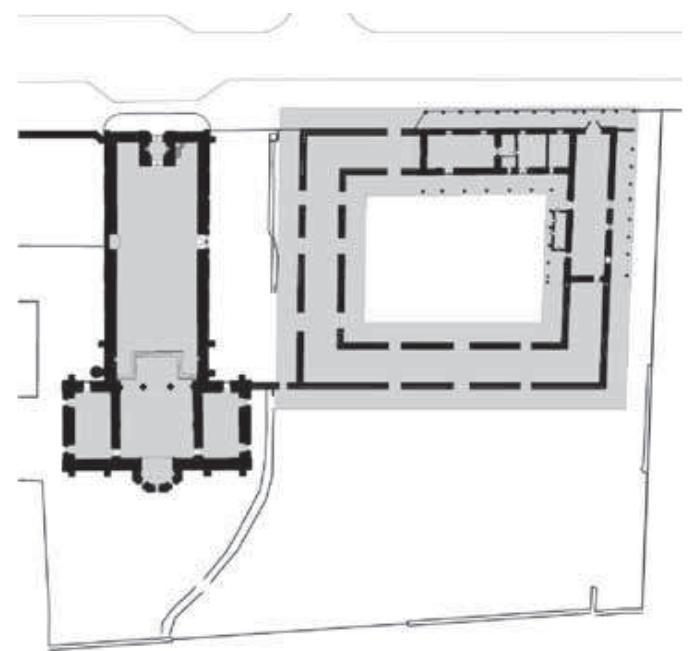

\footnotetext{
${ }^{52}$ La oficina Joannon Arquitectos se adjudicó a fines de 2011 el proyecto de restauración y puesta en valor de la iglesia San José de Pelarco y su casa parroquial, mediante el cual se llevó a cabo un completo estudio histórico, topográfico, de cálculo, etcétera, con el fin de levantar un diagnóstico relativo a los daños y costos. Concluida esta etapa, se convocará a las empresas constructoras que deseen concursar por fondos para trabajar en la reconstrucción de dichos edificios.

${ }^{53}$ Fuente de imágenes 1 a 9: Joannon Arquitectos.
} 


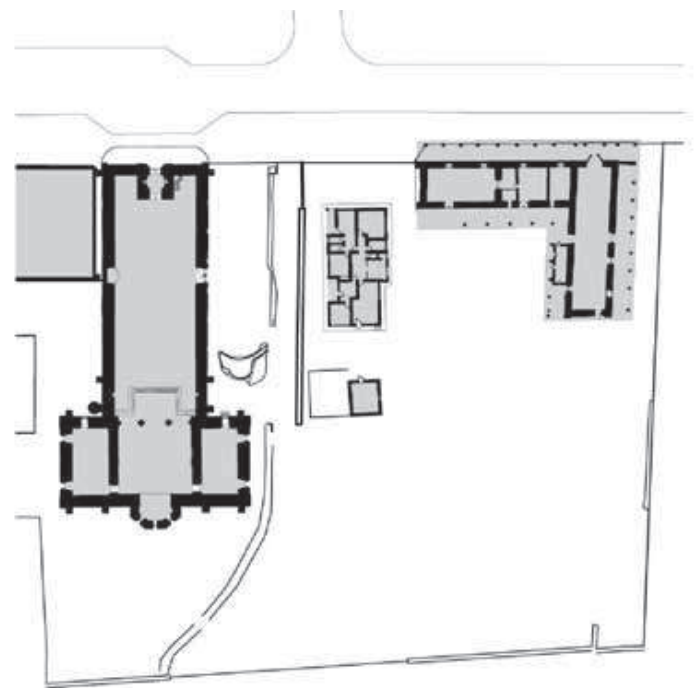

3. Planta de la iglesia actual

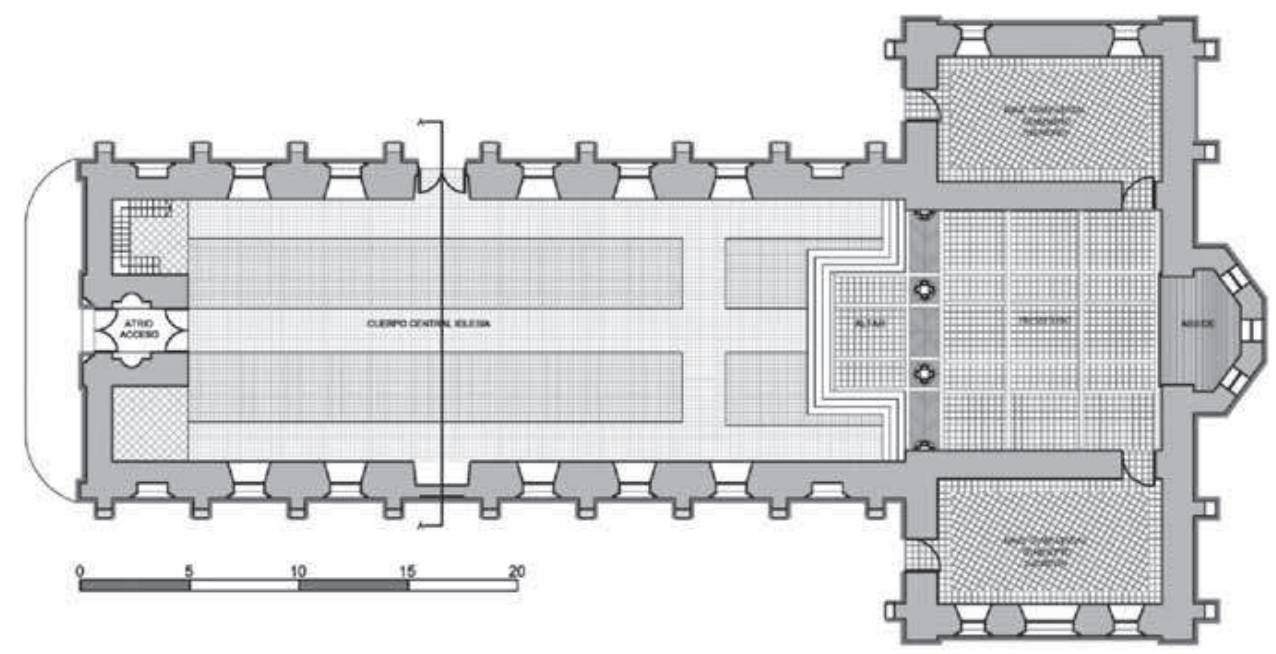

4. Corte longitudinal

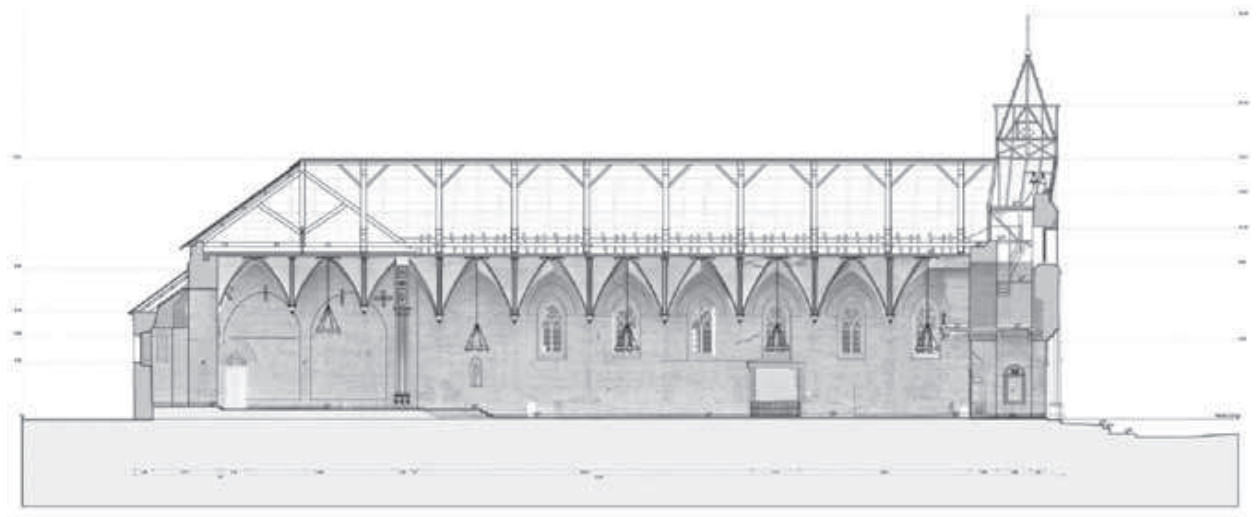




\section{Corte transversal}

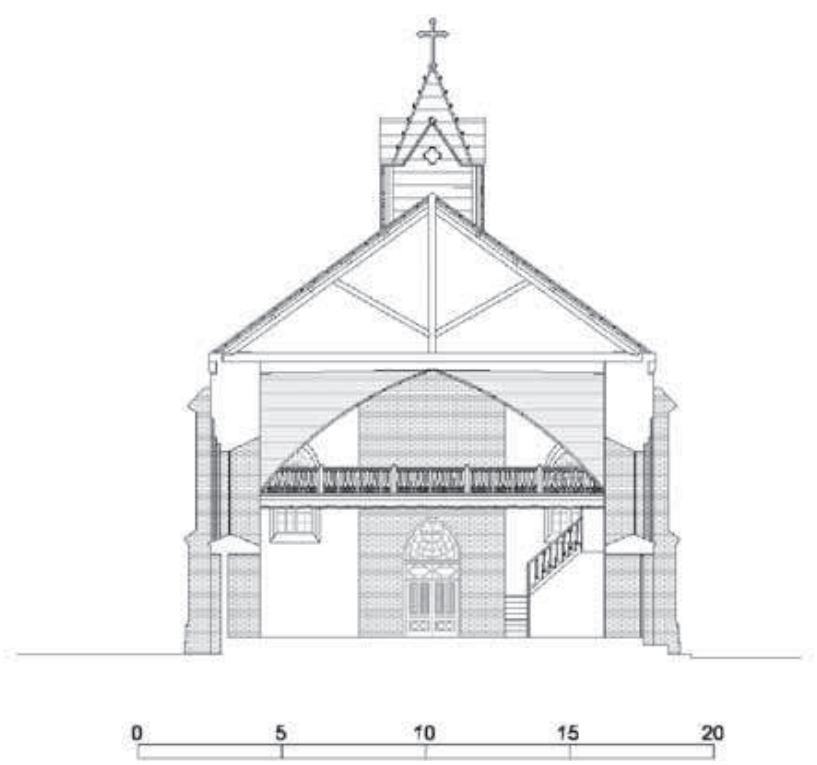

\section{Elevación oriente}

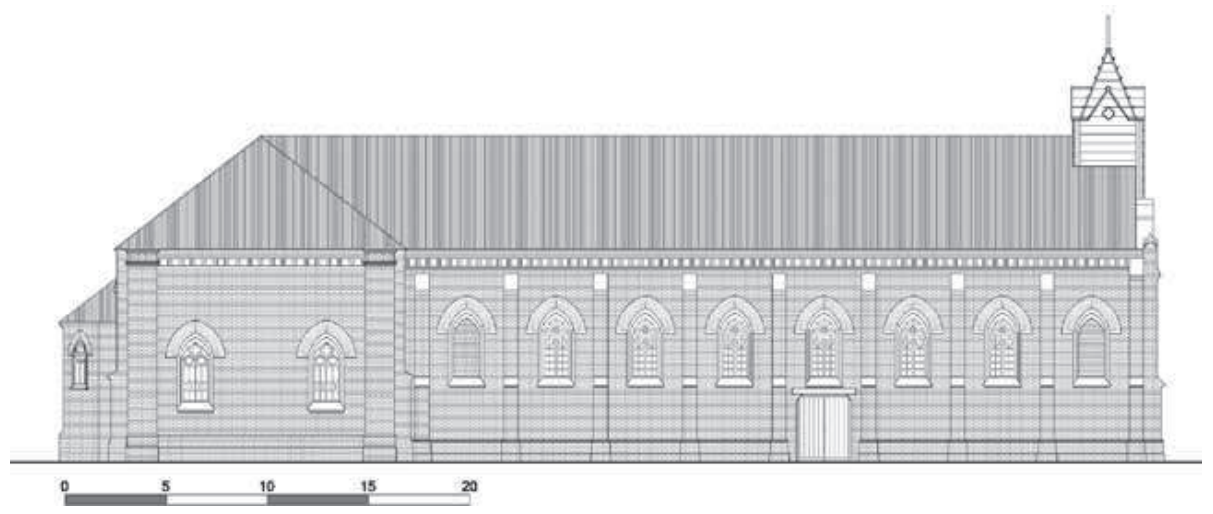

\section{Elevación poniente}

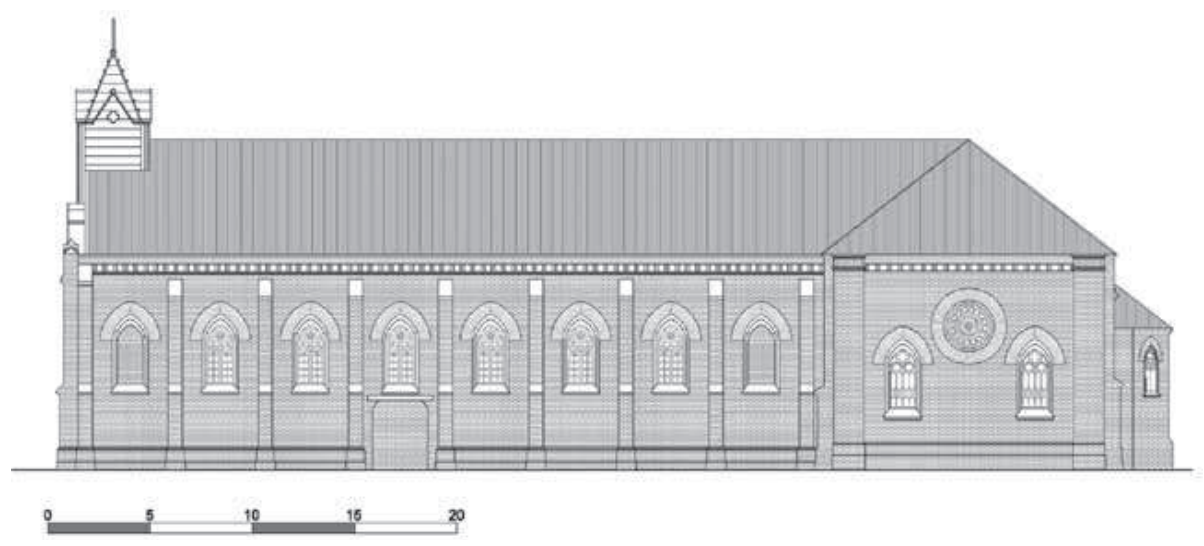




\section{Elevación norte}
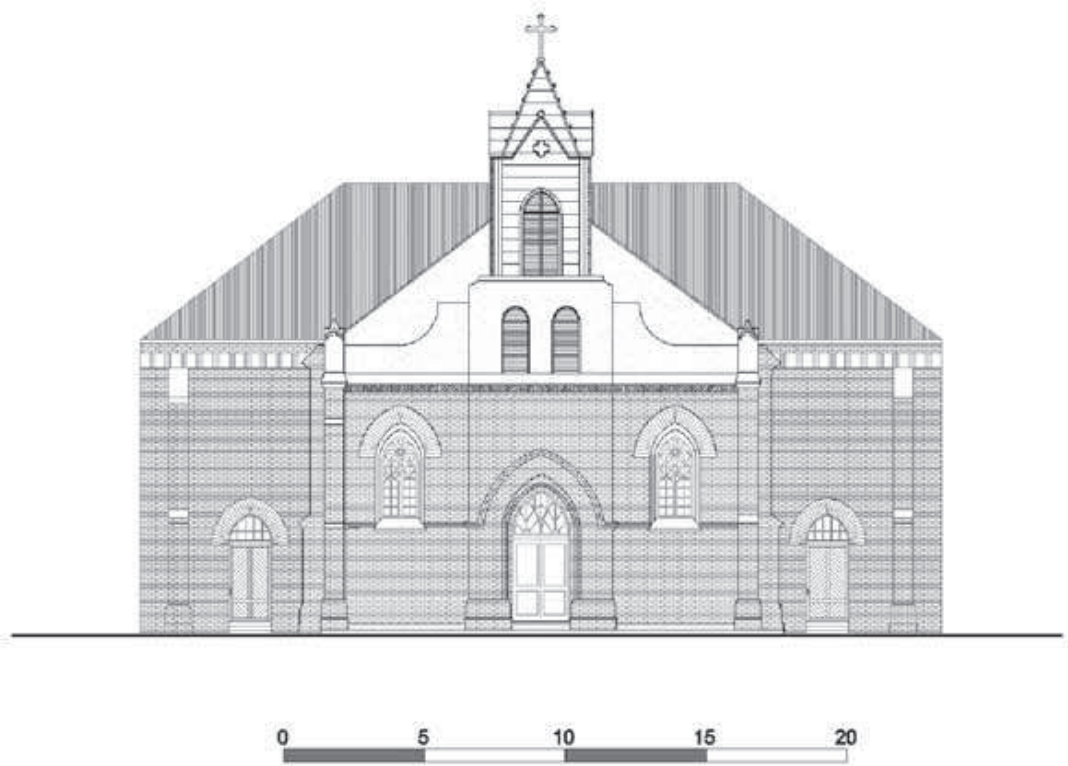

\section{Elevación sur}
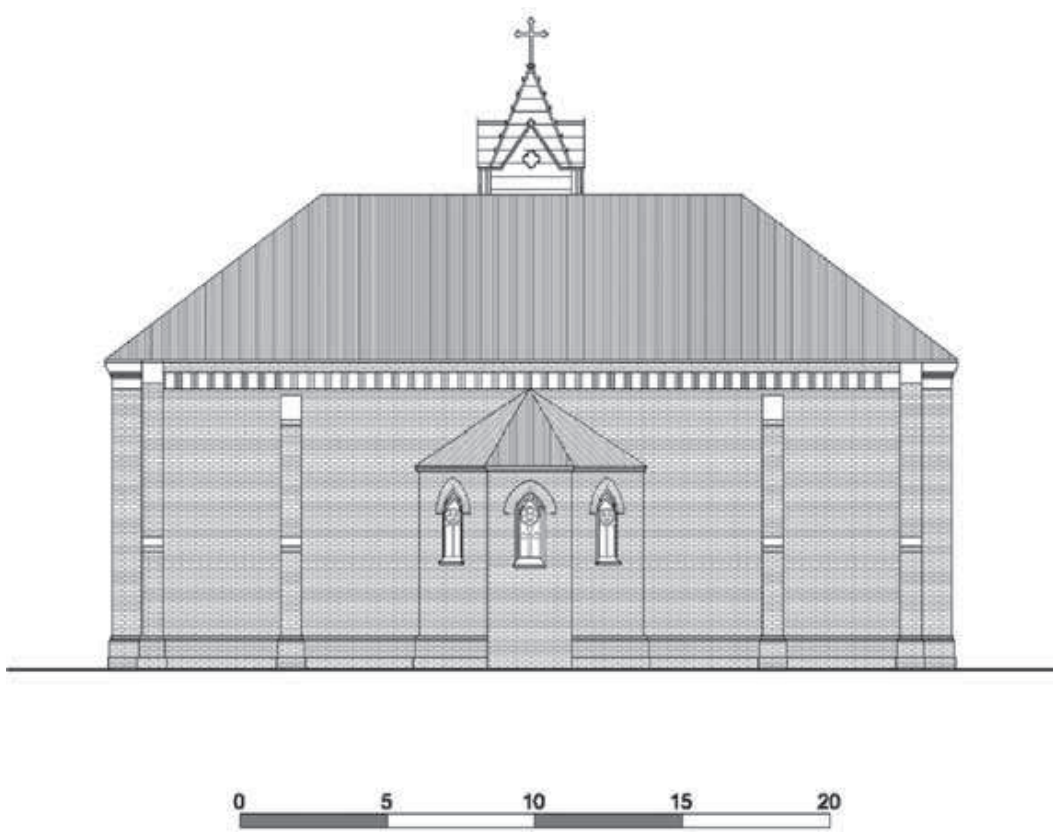
10. Algunos daños del terremoto de febrero de $2010^{54}$

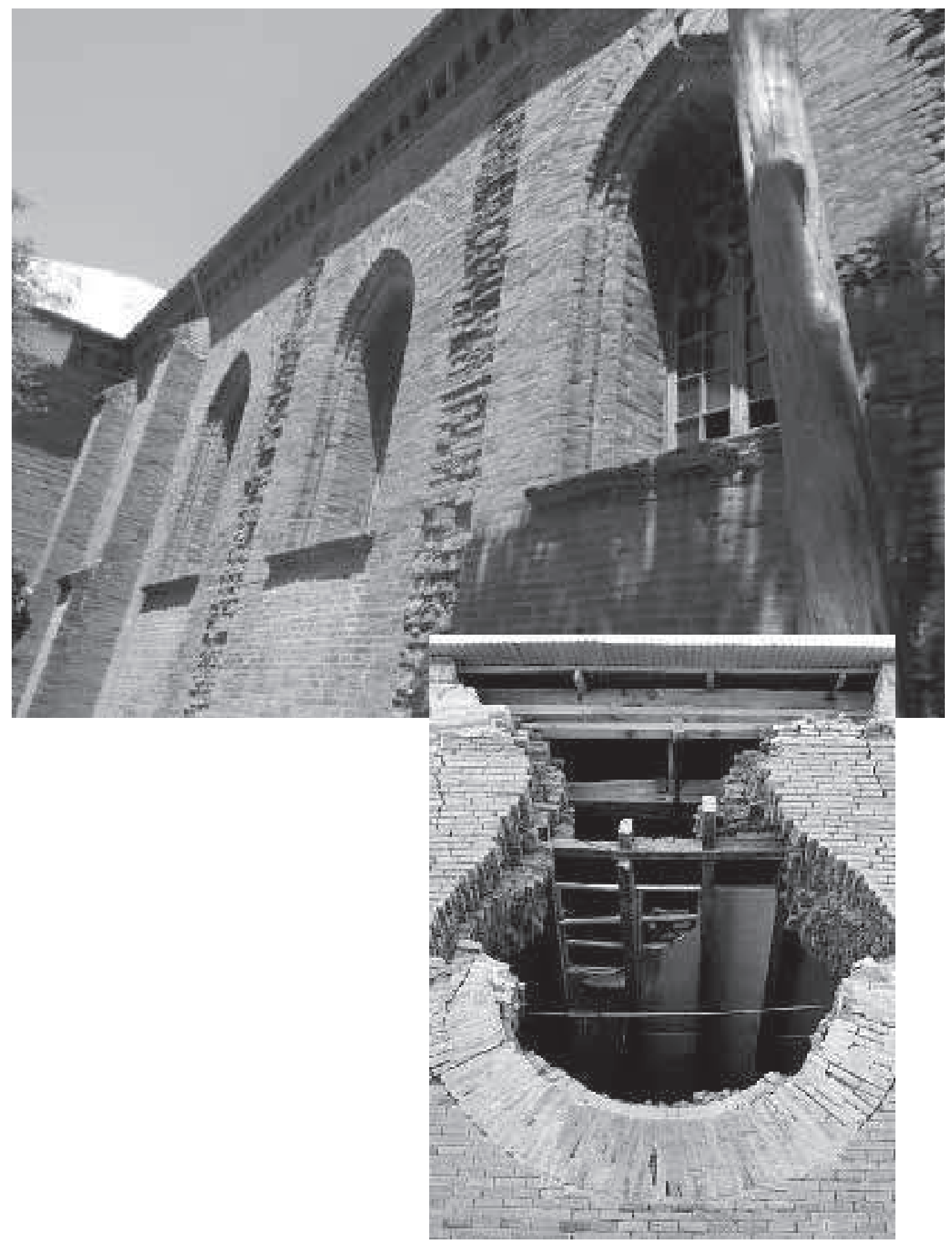

${ }^{54}$ Archivo del Obispado de Talca. 


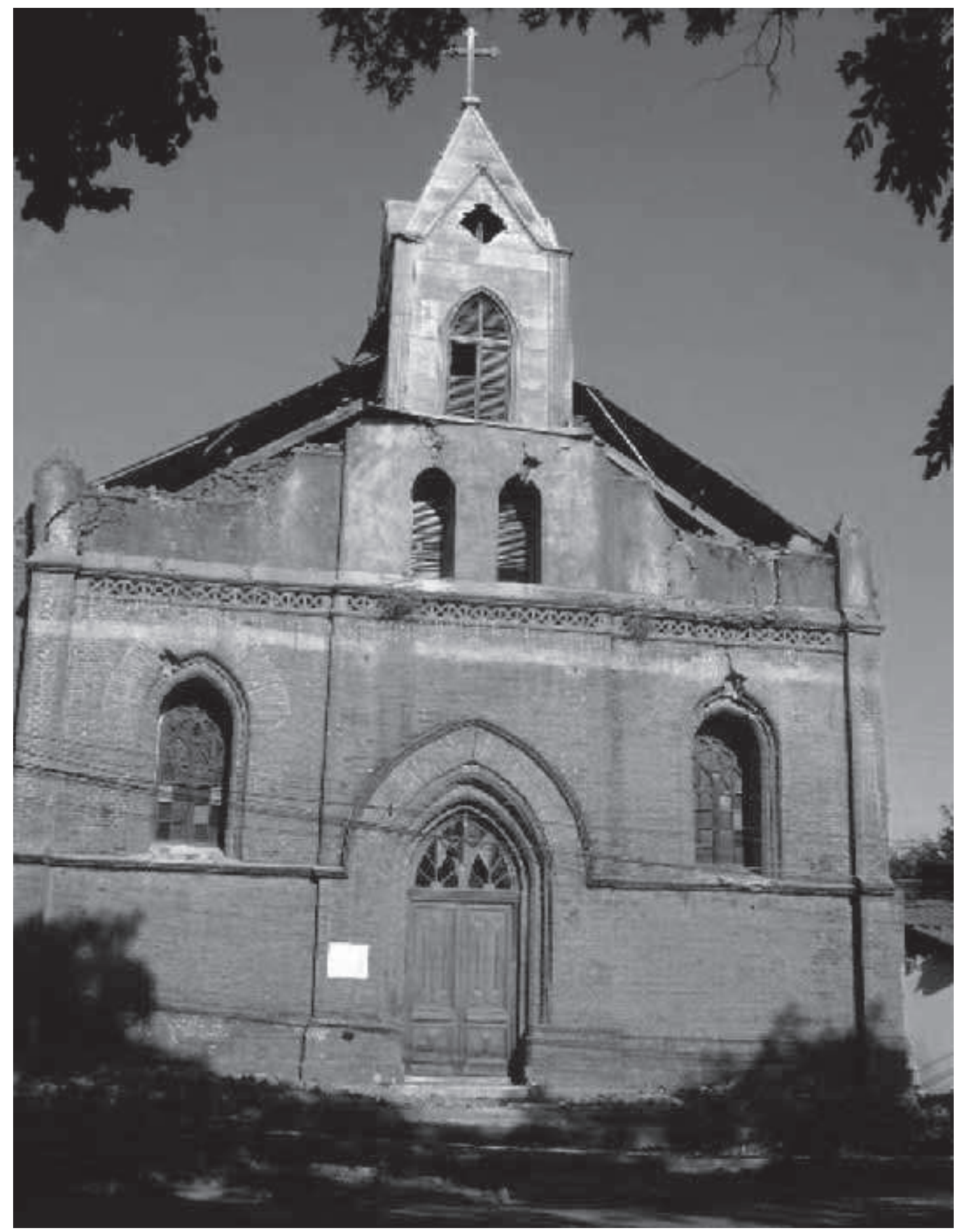




\section{Bibliografía}

\section{Fuentes documentales}

Archivo del Arzobispado de Santiago.

Archivo del Obispado de Talca.

Libros de Fábrica de la parroquia de San José de Pelarco (1787-1950).

\section{Libros y artículos}

Aránguiz Donoso, H., Notas para el estudio de una parroquia rural del siglo XVIII: Pelarco 1786-1796, Universidad Católica de Chile, Santiago, 1969.

Cárdenas, J., Memoria del Maule, Editorial Universidad de Talca, Talca, 2005.

Dirección Regional de Turismo Séptima Región, Bienvenidos al Maule: el corazón de Chile 2004, SERNATUR, Gutenberg, Talca, 2004.

Dirección Regional de Turismo Séptima Región, Guía de museos y monumentos de la Región del Maule, Gutenberg, Talca, 2002.

Fernández, M. A., Religiosidad popular en la Diócesis de Talca: vivencias que evangelizan, Universidad Católica del Maule, Santiago, 2006.

Gobierno Regional del Maule, ¿Tiene Historia mi ciudad? Talca 2010, Gutenberg, Talca, 2010.

González Cruchaga, C., Haciendo memoria en los ochenta años de la Diócesis de Talca, Universidad Católica del Maule, Talca, 2005.

González Martin, I., Talca, la muy noble y muy leal. 250 años de historia (1742-1992), Ediciones Universidad Católica del Maule, Talca, 1992.

Ibáñez Vergara, J., Don Nicolás de la Cruz Bahamonde: el Conde de Maule, Universidad de Talca, Talca, 1997.

Labra, Á., Las primeras capillas e iglesias (con la categoría de Monumento Histórico y/o Zona Típica) en la Región del Maule: una mirada sistémica, FONDART, Talca, 2010.

Molina, J. I., Compendio de la historia geográfica, natural y civil del Reino de Chile, Pehuén Editores, Santiago, 2000.

Opazo Maturana, G., Historia de Talca: 1742-1942, Imprenta Universitaria, Santiago, 1942. 
Programa Puente (Chile), Testimonios de un Chile solidario en la Región del Maule, MIDEPLAN, Gutenberg, Talca, 2005.

Ramírez Vergara, G., Reducción de los fondos para la construcción de obras proyectadas en la provincia de Talca. Observaciones, Imprenta del Instituto Geográfico Militar, Santiago, 1965

Sanhueza Torrealba, S., Estudio de los daños del terremoto de Talca de 1928, memoria para optar al título de ingeniero civil, Universidad de Chile, Santiago, 2002.

Santos Tornero, R., Chile ilustrado. Guía descriptivo del territorio de Chile, de las capitales de provincia, de los puertos principales, Dibam, Santiago, 2011.

Ruiz-Tagle, C.; Pinedo, J. y Zamorano, P., Talca y su muy noble historia, Universidad de Talca, 1994.

Uribe Ortiz, J. L., Disecciones. La arquitectura de las infraestructuras públicas en Talca, FONDART, Talca, 2001.

Valderrama Gutiérrez, J., Episodios históricos talquinos, Editorial Universidad de Talca, Talca, 2008.

Vivar Encina, L., Historia de la aldea "San José de Pelarco", 1994.

\section{Internet}

"Conoce tu región: la iglesia San José de Pelarco, Monumento Nacional", en: diario digital El Amaule, $1^{\circ}$ de enero de 2007, http://www.elmaule.cl/admin/ render/noticia/7438 [Consulta: 3 de diciembre 2011].

Página del Consejo Nacional de la Cultura y las Artes, http://www.pelarco.org/ marco_central_inferior_restauracion.swf [Consulta: 21 de diciembre 2011].

Tapia, Marisol, "La iglesia Patrimonio Histórico de Pelarco", jueves, $1^{\circ}$ de octubre de 2009, http://www.canalpatrimonio.com/es/noticias/? iddoc $=53993$ [Consulta: 6 de diciembre 2011]. 